\title{
Digestive mechanisms in Aplodactylus punctatus (Valenciennes): a temperate marine herbivorous fish
}

\author{
F. Patricio Ojeda, Cristian W. Cáceres*
}

Departamento de Ecología, Pontificia Universidad Católica de Chile, Casilla 114-D, Santiago, Chile

\begin{abstract}
The herbivore Aplodactylus punctatus (Valenciennes) is one of the most abundant fish species inhabiting the rocky subtidal coast of central Chile. To determine the mechanisms of algal digestion in this species, we investigated the $\mathrm{pH}$ pattern along the digestive tract, and its relation to feeding frequency, the occurrence of enzymes capable of hydrolizing cellulose and other related polymers of the algal cell wall, and the distribution and activity of digestive enzymes. Specimens of A. punctatus were collected in 1989 and 1992 from 2 localities of the central Chilean coast. Measurements of $\mathrm{pH}$ and enzymatic assays were carried out on samples of the contents of the stomach, and of the anterior, middle, and posterior portions of the intestine. Both the diet and the gastrointestinal $\mathrm{pH}$ pattern showed no differences between day and night. The stomach was highly acidic ( $p H 2.1$ to 2.6), whereas the intestine was slightly alkaline ( $\mathrm{pH} 6.6$ to 7.8). No enzymatic activity was detected along the digestive tract for the assayed carragenans, agar, and alginates. Cellulase and amylase were found in the intestine but were not present in the stomach. Both enzymes showed the greatest activity in the anterior intestine. Protease (probably pepsin) was mainly found in the stomach. The increased acidity of the stomach, and the cellulolytic activity of the intestine - likely due to microorganisms - strongly suggests that a combination of acid hydrolysis and enzymatic digestion of algal cell wall, followed by digestion of carbohydrates and proteins, would explain the high assimilation rates of plant material reported for this species.
\end{abstract}

KEY WORDS: Herbivorous fish · Digestion · Enzyme activity · Acid lysis

\section{INTRODUCTION}

Recent studies have shown that herbivorous fishes are common components of the marine ichthyofauna of temperate coasts (Horn et al. 1982, Horn 1983, Russell 1983, Choat \& Clements 1992, Barry \& Ehret 1993, Cáceres et al. 1993; see Horn 1989 for a review). Although the ability of herbivorous fish to digest and assimilate algal material has been clearly demonstrated for several temperate fish species (Horn et al. 1986. Anderson 1987, Rimmer \& Wiebe 1987, Horn 1989, Benavides et al. 1994a), the digestive mechanisms that facilitate algal digestion are poorly understood.

\footnotetext{
- Present address: Departamento de Ciencias Ecológicas, Facultad de Ciencias, Universidad de Chile, Casilla 653, Santiago, Chile
}

Several non-exclusive morphological and physiological specializations have been described and suggested that enable herbivorous fishes to obtain the nutrients and energy locked inside algal cells, including: long guts; high rates of food consumption; short transit times; highly acidic stomachs; specialized enzymes able to hydrolyze diverse substrates present in the algal cell wall; and a relatively high assimilation rate (Horn 1989).

Most studies with herbivorous fish have failed to demonstrate the presence of endogenous cellulolytic enzymes in their gut (Horn 1989. Anderson 1991). Instead, breakage of the algal cell wall has been attributed to: (1) lysis due to acidic stomach secretions; (2) mechanical action, resulting from trituration in a pharyngeal mill or gizzard-like stomach (Lobel 1981); or (3) microbially produced enzymes (Rimmer \& Wiebe 1987, Luczkovich \& Stellwag 1993). 
The 'jerguilla' Aplodactylus punctatus is a large herbivorous fish widely distributed along the temperate Pacific coast of South America (Miranda 1973). It is the most abundant species, both in number and biomass, of the littoral fish assemblages of the central Chilean coast (Cáceres et al. 1993). Although the food and feeding habits of $A$. punctatus have received considerable attention (Benavides et al. 1986, Cáceres et al. 1993, Benavides et al. $1994 \mathrm{a}$, b), the mechanisms involved in macroalgal digestion have not yet been investigated.

In this paper we examined: (1) the $\mathrm{pH}$ pattern along the digestive tract of Aplodactylus punctatus, and its relation to feeding frequency; (2) the occurrence of enzymes capable of hydrolyzing the cellulose and other related polymers of the algal cell wall; and (3) the distribution and activity of other digestive enzymes.

\section{MATERIALS AND METHODS}

Collection of specimens. Adult specimens of Aplodactylus punctatus (>28 cm in total length) were collected in 1989 and 1992 in the subtidal zone of 2 localities on the central Chilean coast, Punta de Tralca $\left(33^{\circ} 35^{\prime} \mathrm{S}, 71^{\circ} 42^{\prime} \mathrm{W}\right)$ and Quintay $\left(33^{\circ} 11^{\prime} \mathrm{S}, 71^{\circ} 43^{\prime} \mathrm{W}\right)$, by means of experimental gill nets. The nets were usually set within $1 \mathrm{~h}$ after sunrise and retrieved $1 \mathrm{~h}$ before sunset. After all fish were removed, the nets were set again overnight and retrieved in the morning. Additional specimens were captured in 1992 during the day and night with spearguns

Gastrointestinal pH. Measurements of the $\mathrm{pH}$ along the digestive tract were carried out in fresh specimens captured with spearguns. Immediately after the dissection, an electrode was inserted through slits in the wall of the stomach, and in the anterior, middle, and posterior portions of the intestine. Each measurement was made by using an Orion microelectrode (model 81-03) connected to a digital Orion pHmeter (model SA 210).

Feeding irequency. Feeding frequency was indirectly determined by analyzing and comparing the gut contents of the specimens captured with gill nets during the night and during the day, which should reflect the foraging activity during each period. All specimens captured were weighed to the nearest $g$, measured as total length (TL) to the nearest mm, their stomachs and intestines were dissected, fixed in a $10 \%$ solution of formalin-seawater, placed in labelled plastic bags, and transported to the laboratory for analysis. Prey items were sorted, identified to the finest possible taxonomic resolution, dried in a Memmert oven at $60^{\circ} \mathrm{C}$ for $48 \mathrm{~h}$, and weighed with a $5 \mathrm{mg}$ accuracy.

Enzymatic activity. The enzymatic assays were carried out on samples of the contents of the stomach, and of the anterior, middle, and posterior portions of the intestine. Immediately after each fish was killed, the digestive tract from the oesophagus to the anus was dissected and removed, and placed in ice-cold buffer containing $6.005 \mathrm{~g} \mathrm{l}^{-1}$ hydrogen borate, and $5.26 \mathrm{~g} \mathrm{l}^{-1}$ diethylbarbituric acid, adjusted to $\mathrm{pH} 7.4$ (Anderson 1991). Contents of each section of the digestive tract were drained and placed in individual glass containers. Samples were then sonicated, centrifuged (4500 rpm; $10 \mathrm{~min}$ ) and frozen at $-70^{\circ} \mathrm{C}$ until assayed. All laboratory enzymatic assays were performed at $15^{\circ} \mathrm{C}$, the yearly mean water temperature of the central Chilean coast.

Insoluble carbohydrates. The enzymatic activities were determined for the insoluble carbohydrates, carboxymethylcellulose, carrageenans, agar, and alginates (Sigma Chemical Co.) by measuring the increase in reducing groups following incubation of the substrate with the enzyme (Anderson 1991). Two $\mathrm{ml}$ of substrate [10 $\mathrm{g} \mathrm{l}^{-1}$ of buffer, pH 2.5 (stomach) or 7.8 (intestine)] was incubated with $0.2 \mathrm{ml}$ of homogenate at $15^{\circ} \mathrm{C}$ for $24 \mathrm{~h}$. After centrifuging the incubation mixture (4500 rpm, $10 \mathrm{~min})$, the supernatant was assayed for an increase in reducing sugars following the method of Nelson-Somogyi (Nelson 1952) and calibrated against a standard curve of D-glucose. Enzymatic activity was expressed in terms of $\mu \mathrm{g}$ glucose equivalents produced $\mathrm{h}^{-1} \mathrm{mg}^{-1}$ protein.

Soluble carbohydrates. Amylase activity was determined by incubating $2 \mathrm{ml}$ of soluble starch $\left(10 \mathrm{~g} \mathrm{l}^{-1}\right)$ in buffer with $0.05 \mathrm{ml}$ of homogenate at $15^{\circ} \mathrm{C}$ for $24 \mathrm{~h}$, following the above methodology

Proteases. Protease activity was determined by incubating $2 \mathrm{ml}$ of $2 \%$ bovine serum albumin in buffer at $15^{\circ} \mathrm{C}$ for $24 \mathrm{~h}$ with $0.1 \mathrm{ml}$ of homogenate. The solution was assayed for tyrosine by the method of Lowry et al. (1951). Enzymatic activity was expressed in terms of $\mu \mathrm{g}$ tyrosine equivalents produced $\mathrm{h}^{-1} \mathrm{mg}^{-1}$ protein, and compared to a standard curve prepared from bovine serum albumin.

Data analysis. Log-transformations were applied to adjust for non-normality in the data. Statistical differences in the enzyme activity measured along the gastrointestinal tract were analyzed using a 1-way analysis of variance (ANOVA) followed by StudentNewman-Keuls multiple comparison tests (Zar 1984). Differences in the amount of food contained in the gastrointestinal tract in specimens collected during the day or night were compared with a paired-sample Student's t-test.

\section{RESULTS}

A total of 92 adult specimens of Aplodactylus punctatus ranging in body size from 300 to $1360 \mathrm{~g}$ were 
analyzed, of which 51 were collected during the day and 41 during the night.

\section{Gastrointestinal pH}

The digestive tract of Aplodactylus punctatus showed a significant difference in $\mathrm{pH}$ between the stomach and the 3 portions of the intestine (Fig. 1). Stomach contents were markedly acid, with mean $\mathrm{pH}$ values of $2.74(\mathrm{SE}=0.09)$ and $2.06(\mathrm{SE}=0.41)$ for specimens collected during the day and night, respectively. On the other hand, the $\mathrm{pH}$ throughout the intestine was slightly alkaline, ranging from $\mathrm{pH} 7.68$ to 7.83 and from $\mathrm{pH} 6.63$ to 7.83 for specimens collected during the day and night, respectively (Fig. 1).

\section{Feeding frequency}

Macroalgae were present in all fish analyzed and represented more than $95 \%$ (dry wt) of the total food biomass of the individuals collected during both sunrise and sunset (Fig, 2). No significant differences were detected in the total amount of food contained in the digestive tract of the specimens collected during sunrise or sunset (Student's $t=0.88 \mathrm{p}=0.38$ ), or in the amount of plant and animal material in the gut contents $(t=0.78, \mathrm{p}=0.43 ; t=0.73, \mathrm{p}=0.47$, for algae and animals, respectively) (Fig. 2). A detailed analysis of the diet of this species can be found in Cáceres et al. (1993) and Benavides et al. (1994b).

\section{Enzymatic activity}

Insoluble carbohydrates. No enzyme activity was detected along the digestive tract for the assayed carrageenans, agar, and alginates.

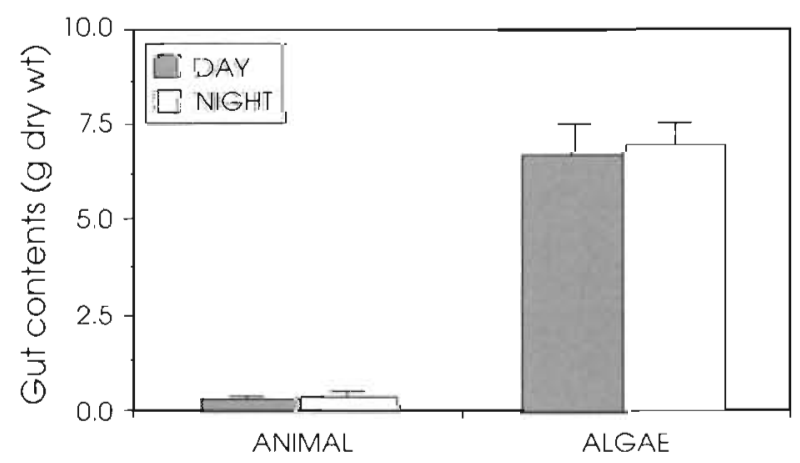

Fig. 2. Aplodactylus punctatus. Variations in algal and animal food contents of specimens caught during the day $(N=51)$ and during the night $(N=41)$. Standard errors are indicated

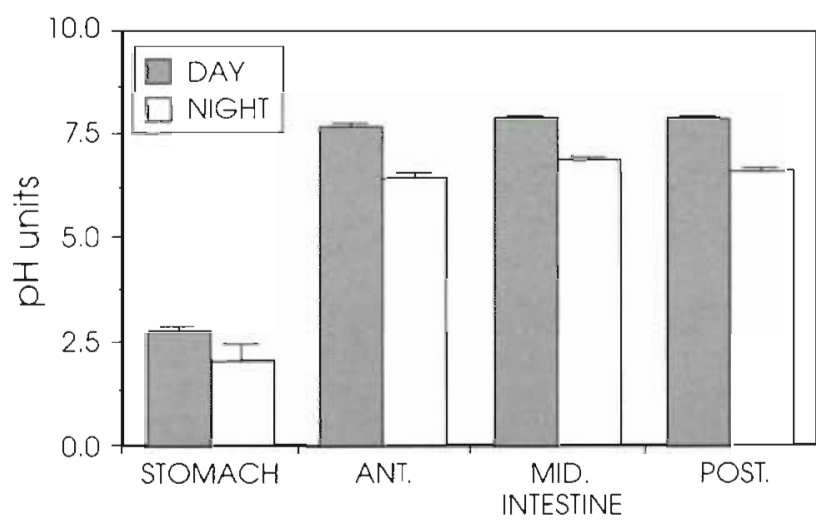

Fig. 1. Aplodactylus punctatus. pH profile of 4 sections of the gastrointestinal tract of specimens caught during the day $(\mathrm{N}=21)$ and during the night $(\mathrm{N}=6)$. Standard errors are indicated

Cellulolytic activity was only observed in the intestine. The activity was significantly greater in the anterior portion than in the middle and posterior portions of the intestine $(p<0.001$; Fig. 3A).

Soluble carbohydrates. Amylase activity was detected only in the intestine of Aplodactylus punctatus. Its activity significantly decreased from the anterior to the posterior portions of the intestine ( $p<0.001$; Fig. 3B).

Protease activity was mainly found in the stomach (Fig. 3C). Because of the acidic conditions of the stomach (see above), it is very likely that this activity corresponds to pepsin (Vonk \& Western 1984).

\section{DISCUSSION}

The importance of acid lysis as an effective mechanism for breaking the algal cell wall has been strongly suggested for a number of herbivorous fishes (Lobel 1981, Horn 1989, Anderson 1991), particularly for those fishes possessing thin-walled stomachs and no trituration mechanism other than jaw bite (Horn 1989). Aplodactylus punctatus has a thin-walled stomach, a long intestine, and does not possess any kind of mechanical triturating mechanism (Cáceres et al. 1993).

The results of this study show that the gastric $\mathrm{pH}$ of Aplodactylus punctatus is markedly low ( $\mathrm{pH} 2.1$ to 2.7 ) compared to the intestinal $\mathrm{pH}$ values $(\mathrm{pH} 6.5$ to 7.8$)$. This gastrointestinal $\mathrm{pH}$ pattern is similar to those reported for other herbivorous fishes (Lobel 1981, Edwards \& Horn 1982, Anderson 1991; see Horn 1989 for a review). Experimental analyses of the effect of different $\mathrm{pH}$ concentrations in marine macroalgae have shown that exposure at low $\mathrm{pH}(2.0$ to 3.0$)$ was effective in lysing algal cells of some algal species (Lobel 1981, Urquhart 1984 cited in Horn 1989). 

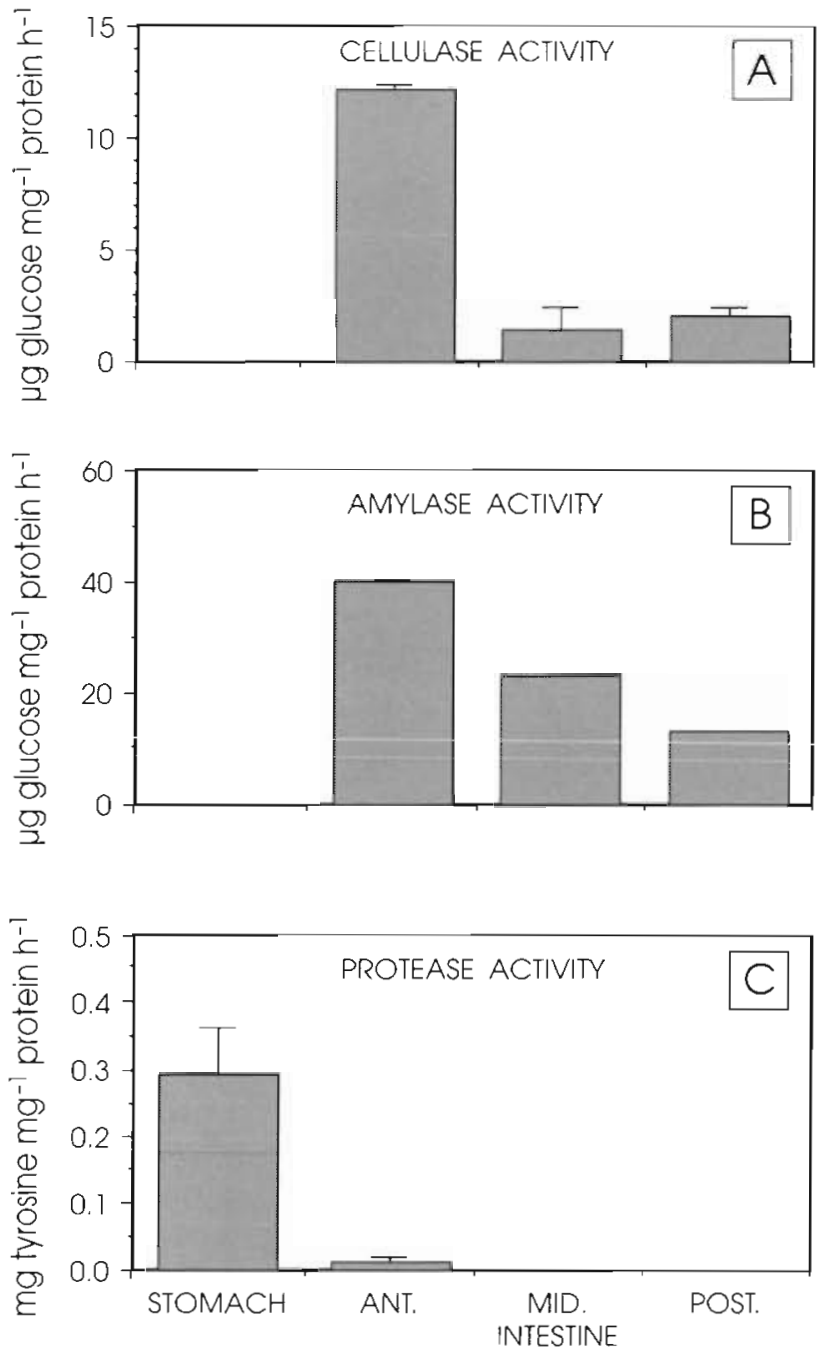

Fig. 3. Aplodactylus punctatus. Enzymatic activity of the contents of 4 sections of the gastrointestinal tract. (A) Cellulase activity, (B) amylase activity, (C) protease activity. Sample size was 6 for all assays. Standard errors are indicated

Similar results were obtained by Ojeda et al (1991), who found that acid lysis of the cell wall of the green alga Ulva sp. and of the brown kelp Lessonia trabeculata Villouta et Santelices significantly increased the concentration of organic matter in the acidic medium ( $\mathrm{pH} 2.7$ for $2 \mathrm{~h}$ ) compared to control solutions ( $\mathrm{pH} 7.3$ ). This strongly suggests acid hydrolysis is an important mechanism by which some herbivorous fish gain access to the nutrients locked inside the algal cell walls.

The presence of large quantities of algal food (mainly fronds of the brown kelp Lessonia trabeculata) along the whole digestive tract of all specimens of Aplodactylus punctatus examined (Fig. 2) indicates this species is an active browser, foraging regularly during day and night. Further, the similar gastro- intestinal $\mathrm{pH}$ profiles observed in the individuals collected during day and night (Fig. 1) suggests digestion of algal food also takes place during both periods.

The results of this study show that Aplodactylus punctatus does not possess specialized enzymes, other than cellulase, capable of breaking down the algal cell wall. Cellulase activity was relatively low and mainly detected in the anterior intestine of the specimens sampled (Fig. 3A). Although we did not study the microorganisms present in the gut of A. punctatus, such activity could be attributed to endosymbiotic microbial flora resident in the intestinal tract (Rimmer \& Wiebe 1987), because no vertebrate has been shown to produce endogenous cellulase (Barnard 1973).

Numerous other studies have been conducted to elucidate whether herbivorous fish produce enzymes capable of degrading the structural polysaccharides present in the algal cell wall. Some of these studies have found evidence of cellulase activity in the guts of herbivorous fishes, but it was not usually related to their food habits. Stickney \& Shumway (1974), for example, attributed such enzymatic activity to intestinal microorganisms, whlle others related it to the amount of decayed plant detritus in the gut (Prejs \& Blaszczyk 1977), or to the microflora occurring in some invertebrate prey present in the fish gut (Niederholzer \& Hofer 1979, Lindsay \& Harris 1980). Weinstein et al. (1982), on the other hand, documented cellulase activity in the intestinal tract of the sparid Lagodon rhomboides (L.). They suggested the cellulase was of endogenous origin. This finding has recently been questioned by Luczkovich \& Stellwag (1993), who were the first to isolate cellulase-producing microbes from the intestinal tract of any fish. Their results strongly suggest that endosymbionts play an important physiological role in digesting algal cell walls.

Digestive enzymes found in the gastrointestinal tract of Aplodactylus punctatus follow similar patterns to those described for other fish species (Kapoor et al. 1975, Fänge \& Grove 1979, Anderson 1991, Sabapathy \& Teo 1993).

Amylase activity was restricted to the intestine of Aplodactylus punctatus, though its activity sharply declined from the anterior to the posterior intestine (Fig. 3B), thus suggesting that sugar absorption readily occurs after cell wall degradation.

Protease activity was mainly found in the stomach (Fig. 3C), and it was most likely due to pepsin, because this enzyme has been reported in most fish species having a true stomach (Vonk \& Western 1984). This enzyme has an optimal pH of about 2 (Fänge \& Grove 1979), which corresponds with the mean $\mathrm{pH}$ value observed in the stomach of $A$. punctatus.

Based on the results of this study and others published elsewhere (Cáceres et al. 1993, Benavides et al. 
$1994 \mathrm{~b})$, it is possible to formulate a model explaining the digestive mechanism for Aplodactylus punctatus. According to the chemical reactor theory (Penry \& Jumars 1987, Horn \& Messer 1992), the alimentary canal of $A$. punctatus - characterized by a thin-walled stomach and long intestine - can be modeled as a continuous-flow, stirred-tank reactor (CSTR) followed by a plug-flow reactor (PFR). Algal food is stored and mixed in the stomach under highly acidic conditions (CSTR). Subsequently, algal pellets are released in constant pulses into the intestinal lumen for final enzymatic digestion (PFR). According to Horn \& Messer (1992), this model predicts that the reaction rate will be low for a fish with a high-concentration diet but a very low throughput time, and a moderately long intestine. A. punctatus has been characterized as being a sluggish and negatively buoyant fish (Benavides et al. 1994a), with a relative intestine length of about 3 (of the total length) (Cáceres et al. 1993), and a mean food throughput time of $40 \mathrm{~h}$ (Benavides et al. 1994b). These characteristics agree with the model.

In conclusion, the high acidity of the stomach and the cellulolytic activity of the intestine strongly suggest that a combination of acid hydrolysis and enzymatic digestion of algal cell walls, followed by digestion of carbohydrates and proteins, constitute the main digestive mechanisms of Aplodactylus punctatus. This would explain the high assimilation rates of plant material reported for this species (Benavides et al. 1994b).

Acknowledgements. We thank G. Benavides, J. M. Fariña, L. Fuentes, A. Palma, and P. Zavala for important assistance in the field, and to E. O. Campos for his valuable help in the laboratory analysis. Drs F. Jaksic, P. Marquet, J. Lawrence and Ph.D. candidate P. Camus provided helpful comments on an earlier version of the manuscript. This research was supported by a FONDECYT grant no. 0753-91 to F.P.O. C.W.C. is presently funded by a CONICYT Doctoral Fellowship.

\section{LITERATURE CITED}

Anderson, T. A. (1991). Mechanism of digestion in the marine herbivore, the luderick, Girella tricuspidata (Quoy and Gaimard). J. Fish Biol. 39: 535-547

Barry, J. P., Ehret, M. J. (1993). Diet, food preference, and algal availability for fishes and crabs on intertidal reef communities in southern California. Environ. Biol. Fish. $37 \cdot 75-95$

Barnard, E. A. (1973). Comparative biochemistry and physiology of digestion. In: Prosser, C. L. (ed.) Comparative animal physiology, 3rd edn. W. B. Saunders, Philadelphia, p. $133-164$

Benavides, A. G., Bozinovic, F., Cancino, J M., Yates, L. (1986). Asimilación de algas por dos peces del litoral chileno: Syciases sanguineus (Gobiesocidae) y Aplodactylus punctatus (Aplodactylidae). Medio ambiente 8: 21-26

Benavides, A. G., Cancino, J. M., Ojeda, F. P. (1994a). Ontogenetic change in the diet of Aplodactylus punctatus
(Pisces: Aplodactylidae): an ecophysıological explanation. Mar. Biol. 118: 1-.

Benavides, A. G., Cancino, J. M., Ojeda, F. P. (1994b). Ontogenetic changes in gut dimensions and macroalgal digestibility in the marine fish Aplodactylus punctatus. Funct. Ecol. 8: 45-51

Cáceres, C. W. Benavides, A. G., Ojeda, F. P. (1993). Ecologia trófica del pez herbivoro Aplodactylus punctatus (Pisces: Aplodactylidae) en la costa centro-norte de Chile. Rev. Chil. Hist. Nat. 66: 185-194

Choat, J. H., Clements, K. D. (1992). Diet in odacid and aplodactylid fishes from Australia and New Zealand. Aust. J. mar. Freshwat. Res. 43: 1452-1459

Edwards, T. W. Horn, M. H. (1982). Assimilation efficiency of a temperate-zone intertidal fish (Cebidichthys violaceus) feds diets of macroalgae. Mar. Biol. 67: 247-253

Fänge, R., Grove, D. (1979). Digestion. In: Hoar, W. S., Randall, D. J., Brett, J. R. (eds.) Fish physiology, Vol. VII. Academic Press, New York, p. 161-204

Horn, M. H. (1983) Optimal diets in complex environments: feeding strategles of two herbivorous fishes from a rocky intertidal zone. Oecologia 58: 345-350

Horn, M. H. (1989). Biology of marine herbivorous fishes. Oceanogr. mar. Biol. A. Rev. 27: 167-272

Horn, M. H., Messer, K. H. (1992). Fish guts as chemical reactor: a model of the alimentary canals of marine herbivorous fishes. Mar. Biol. 113:527-535

Horn. M. H., Murray, S. N., Edwards, T W. (1982). Dietary selectivity in the field and food preferences in the laboratory for two herbivorous fishes (Cebidichtys violaceus and Xiphister mucosus) from a temperate intertidal zone. Mar Biol. 67: 237-246

Horn, M. H., Neighbors, M. A., Murray, S. N. (1986). Herbivore responses to a seasonally fluctuating food supply growth potential of two temperate intertidal fishes based on the protein and energy assimilated from their macroalgal diets. J. exp. mar. Biol. Ecol. 103: 217-234

Kapoor, B. G., Smith, H., Verhina, I A. (1975). The alimentary canal and digestion in teleost. Adv. mar. Biol. 13: 109-239

Lobel, P. S. (1981). Trophic biology of herbivorous reef fishes: alimentary $\mathrm{pH}$ and digestive capabilities. J. Fish Biol. 19: $365-397$

Lowry, O. H., Rosenbrough, N. J., Farr, A. L. Randall, R. J. (1951). Protein measurement with the Folin reagent. J. biol. Chem. 193: 265-275

Lindsay, G. J. H., Harris, J. E. (1980). Carboxymethylcellulase activity in the digestive tract of fish. J. Fish Biol. 16: $219-233$

Luczkovich, J. J., Stellwag, E. J. (1993). Isolation of cellulolytic microbes from the intestinal tract of the pinfish, Lagodon rhomboides: size-related changes in diet and microbial abundance. Mar. Biol. 116: 381-388

Miranda, O. (1973). Calendario ictiológico de San Antonio. 3. Biología de la Jerguilla (Aplodactylus punctatus). Biol. pesq. Chile 6: $25-43$

Nelson, M. (1952). A photometric adaptation to the Somogyi method for the determination of glucose. J. biol. Chem. 195: $375-380$

Niederholzer, R., Hofer, R. (1979). The adaptation of digestive enzymes to temperature, season and diet in roach Rutilus rutilus L. and rudd Scardinus erythrophthalmus L. J. Fish Biol. 15: 411-416

Ojeda, F. P., Cáceres, C. W., Benavides, A. G. (1991). Mecanismos de digestión de algas por peces herbívoros: rol del $\mathrm{pH}$ gastrico. Abstract. 34th annual meeting of the Sociedad de Biologia de Chile. Arch. Biol. Med. exp. 24: R195 
Penry, D. L.. Jumars, P. A. (1987). Modeling animal guts as chemical ruactors. Am. Nat. 129: 69-96.

Prejs, A., Blašczyk, M. (1977). Relationships between food and cellulase activity in freshwater fishes. J. Fish Biol 11: $447-452$

Rimmer, D. W., Wiebe, W. J. (1987). Fermentative microbial digestion in herbivorous fishes. J. Fish Biol. 31. 229-236

Russell, B. C. (1983). The food and feeding habits of rocky reef fishes of north-eastern New Zealand. N.Z. J. mar. Freshwat. Res. 17: 121-145

Sabapathy, U., Teo, L. H. (1993). A quantitative study of some digestive enzymes in the rabbitfish, Siganus canaliculatus

This article was submitted to the editor and the sea bass, Lates calcarifer. J. Fish Biol. 42: 595-602 Stickney, R.R., Shumway, S. E. (1974). Occurrence of cellulase activity in the stomachs of fishes. J. Fish Biol. 6: 779-790 Vonk, H. J., Western, J. R. H. (1984). Comparative biochemistry and physiology of enzymatic digestion. Academic Press, Inc., London

Weinstein, M. P., Heck, K. E. Jr, Gieble, P. E., Gates, J. E. (1982). The role of herbivory in pinfish (Lagodon rhomboides): a preliminary investigation. Bull. mar. Sci. 32: $791-795$

Zar, J. H. (1984). Biostatistical analysis. Prentice-Hall, Englewood Cliffs, NJ

Manuscript first received: July 20, 1994

Revised version accepted: November 10, 1994 